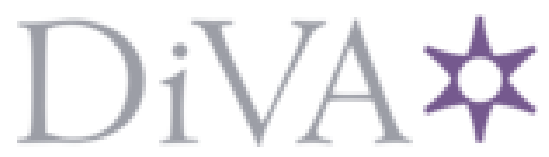

http://www.diva-portal.org

This is the published version of a paper published in The Journal of Belarusian Studies.

Citation for the original published paper (version of record):

Kotljarchuk, A. (2013)

World War II Memory Politics: Jewish, Polish and Roma Minorities of Belarus.

The Journal of Belarusian Studies, 1: 7-40

Access to the published version may require subscription.

N.B. When citing this work, cite the original published paper.

Permanent link to this version:

http://urn.kb.se/resolve?urn=urn:nbn:se:sh:diva-24666 


\title{
World War II Memory Politics: Jewish, Polish and Roma Minorities of Belarus
}

BY

\author{
ANDREJ KOTLJARCHUK*
}

'No one is forgotten, nothing is forgotten!'

Olga Bergholz, 1960

A popular slogan used by the Soviet authorities in regard to WWII.

The aim of this study is to interpret recent trends in contemporary memory politics in Belarus, with focus on the Holocaust, Roma genocide memorials, and the memorial sites of the Polish minority in Belarus. The author believes that the theory of 'path dependence' is suitable for analysis of contemporary Belarusian memory politics with respect to World War II. In accordance with this theory, the scope and limitations of new politics are determined by the political choices made or results attained much earlier by the previous political regime. Recent comparative political studies adapt the 'path dependence' concept to historical material (Hedlund 2005). From this point of view, a comprehensive analysis of contemporary Belarusian memory politics is not possible without an examination of the Soviet period.

In his study on the memorialization of the Holocaust in Poland, Hungary and Slovakia Jeffrey Blutinger defines three basic approaches to contemporary memory politics in Eastern Europe. The first approach, 'aphasia', means a virtual taboo on memory typical for the communist age. The second stage, 'deflective negationism', means that the Holocaust is recognised, but all responsibility for it is placed exclusively on the Germans. At the same time, the problem of local collaborationism is slurred over. Finally, the third model, 'open examination',

\footnotetext{
Andrej Kotjlarchuk, PhD is a Senior Lecturer at the Institute of Contemporary History, Södertörn University, Sweden. This study was supported by Södertörn University and the Foundation for Baltic and Eastern European Studies (Stockholm). The author wishes to thank Per Anders Rudling, Uladzimir Ščerbaŭ, Aliaksiej Lastoŭski, Arnold McMillin, Tomislav Dulić and two anonymous reviewers for their comments.
} 
means the removal of all taboos (Blutinger 2010, 73-94). From this point of view, it is interesting to find out at which stage is today's Belarus.

The theoretical model of the article is based on the concept of sites of memory developed by Pierre Nora and Lawrence Kritzman. They argue that memory shapes the future by determining our attitude to the past. Crystallised memories are extremely powerful factors in the mobilization of ethnic group and the strengthening of their identity. The sites of memory, considered by these scholars very broadly (that is images on banknotes or movies), are an extremely powerful factor in the consolidation of a nation and mobilization of ethnic groups. The process of inclusion of an ethnic minority's collective memory into a national context takes place through sites of memory (Nora and Kritzman 1996 and 1997).

The authorities are not interested strictly in history but in memory which always has a strongly engaged political meaning. It is interesting to follow the history of sculptural projects for public monuments that did not secure the approval of the authorities (in other words, failed the contest) and were never implemented. While history belongs to science and is associated with a critical understanding of past events through area studies, memory is coupled with contemporary politics and the dedicated creation of a historical myth capable of uniting different ethnic and social groups in society.

The memorial politics crystallise in sites of memory, amongst which the most influential ones are memorials, because the physical space of memory is created through them, connecting together a historical event, a remembrance day and participants of the ceremony (Baer 2000, Pickford 2005). The memorial gives sacral meaning to the landscape, which helps to create the national iconography of a contemporary state. In a democratic state, memory politics are a common action field for the authorities and society that, in its turn, has important leverage (independent media etc.). In a totalitarian state, the government has virtual monopoly over public memory, deciding what to remember and what to forget (Schäuble 2011, 24).

The idea of raising monuments to the dead did not originate with World War II, but no other war gave birth to so many. A typical war memorial gives the following information: a short description and chronology of tragic events, the number or list of victims, information about the criminals and words addressed to the victims' descendants. Important is not only the sculptural group but also the place chosen by the authorities for the monument (a central or marginal point of the cultural landscape). The language or languages of the monument play a major role. Thus, a language that the majority of the population does not understand refers to the ethnic meaning of the site of memory, even when ethnicity cannot be guessed directly. In most cases, an inscription in the language of a minority is accompanied 
by an inscription in the official language. This is the practice in most European countries, and Belarus is no exception.

The inscription on a public monument must be approved by the authorities and is the ultimate, canonised and embedded in concrete viewpoint of the government on events of the past. The process of monumentalizing the new canon of historical memory takes time. The common features of this process can be represented in the following way:--

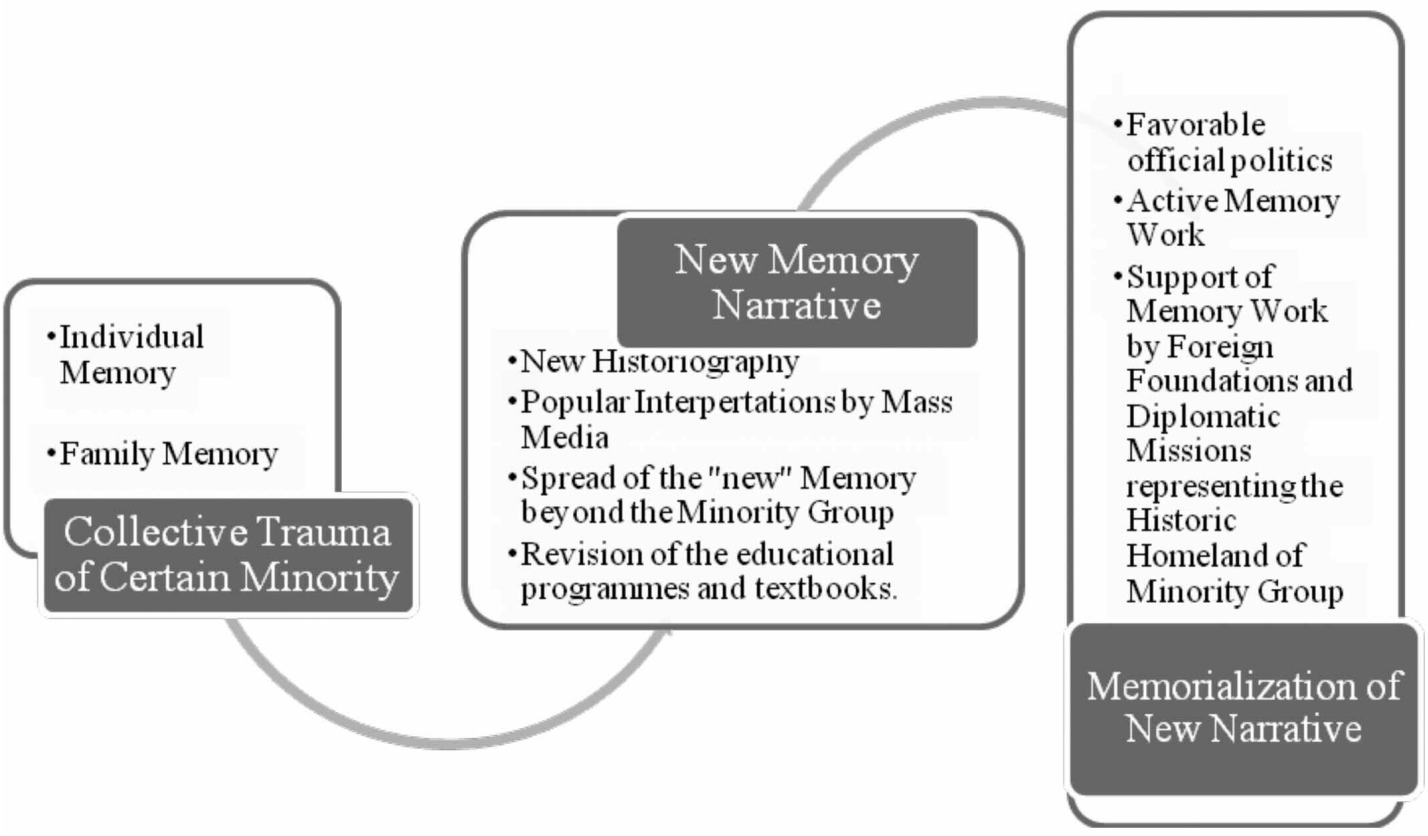

\section{'One in Four'. World War II and Its Victims in Belarus}

Belarus suffered more than most other European countries in World War II. According to official data, human casualties amounted to more than 2.2 million people; 380 thousand young people were taken to Germany for compulsory labour (Pase 1994, 433-34). As Vitali Silitski pointed out, the war casualties of the Belarusian population were 'more than French, British, and American casualties combined. Six hundred villages were burned, together with their residents; life never returned to 200 of them. An entire country - that is, every single major city - was left in ruins. The population returned to its pre-war level only in the mid1970s' (Silitski 2005).

Public spaces in today's Belarus use the Soviet name for the war, the 'Great Patriotic War', which embraces the period 1941-45. Belarusian scholars use both designations: 'World War II' when they refer to the period 1939-45 or about the military operations of the allied forces outside of the Soviet Union, and the 'Great Patriotic War' when they refer to the Nazi occupation of Belarus. According to Per 
Rudling, World War II in particular became a foundation for the creation of modern Belarusian identity. As a matter of fact, there is no historical event with greater influence on today's Belarus (Rudling 2010, 91). There is good reason that this national trauma has deeply penetrated the public discourse and self-awareness of Belarusians. The Belarusian language is probably the only language in the world where the word 'war' is used as a synonym of World War II.

The first information about the more than two million inhabitants of Belarus that perished appeared during the war in one of the partisans' war-time consolidated reports when it was not possible to make any exact calculation. In 1943, the 'Extraordinary State Commission for ascertaining and investigating crimes perpetrated by the German - fascist invaders and their collaborators' estimated the number of victims in Soviet Belarus at 2.2 million people per population of around 10.5 million people as of 1 January 1941. During Soviet times, this figure included 800 thousand prisoners of war (most of whom were not citizens of the republic) and 1.4 million civilians (Ničoha nie zabudziem 1943, Litskevich 2009).

On the basis of the claimed figures, a myth about 'every fourth inhabitant of the republic' who perished was created, which did not fit even the broadest mathematical calculations. The myth's author was Piotr Mašeraŭ, the leader of Soviet Belarus in the years 1965 to 1980 . This Belarusian, a former commander of a partisan unit and a war hero (he received the Gold Star of the Hero of the Soviet Union in 1944), was appointed First Secretary of the Central Committee of the Communist Party of Belarus in 1965. In his very first public speech dedicated to the 20th anniversary of victory in World War II Mašeraŭ said: 'The war claimed the lives of almost every fourth inhabitant of the republic' (Masherov 1965). The leader of the republic repeated this affirmation on many occasions, for instance in his solemn declaration dedicated to the 25th anniversary of the liberation of Belarus from the Nazis (Masherov 1969). ${ }^{1}$ In 1970, the Belarusian Soviet Encyclopaedia, an authoritative source at that time, claimed that during the war Belarus had lost '2,200 thousand people - every fourth inhabitant of the republic died' (Bielaruskaja Savieckaja Encyklapiedyja 1970, vol. 2, 265). The ethnic origins of the victims were not indicated. Contrary to the slogan 'No one is forgotten, nothing is forgotten', the fact that Jews made up a considerable part of the victims among civilians was consistently omitted.

The question of the number of victims of the Nazi occupation remains debatable in Belarusian historiography (Litvin 2003). It is still not known exactly how many civilians died. The figures of casualties among civilians vary from 1.4 million to 750 thousand people. ${ }^{2}$ It is also unclear what was the exact share of Jews and Roma slaughtered in the Nazi genocide, and the human losses in Belarus should include

1 The author wishes to thank M.A. Uladzimir Ščerbaŭ for this reference. 
the number of inhabitants of Western Belarus who were murdered and deported during the Stalinist terror of 1939-41, those who died from natural causes and, finally, the collaborators and volunteers who left the country in 1944 together with the retreating German army.

\section{Memory Politics of the Soviet Era}

Five nationally important memorials of World War II were erected during the Soviet era in Belarus:

- The Victory Monument in Minsk (1954)

- The State Memorial Complex 'Chatyń' (1969)

- The State Memorial Complex 'Brest Hero-Fortress' (1969-71)

- The Mound of Glory to the Soviet Army, Liberator of Belarus (1969)

- The State Memorial Complex ‘Breakthrough' (1974)

Only one out of five memorials was dedicated to non-combatant victims of Nazism. This is Chatyń (Khatyn) which was built on the site of a former village in Lahojsk district, Minsk region. The population of this village was fully exterminated by the Nazis and their collaborators in 1943 for alleged assistance to Soviet partisans (Rudling 2012). The Chatyń Memorial was created under Piotr Mašeraŭ's leadership and shows imprints of his memory politics.

The central position in the memorial is given to the Memory Square. Three birch trees were planted there as a symbol of life, and in place of a fourth one, they built an 'eternal light' as a symbol of all who had perished. Next to the fire an inscription was made: 'Two million 230 thousand. Every fourth person died'. The statistics cast in stone had a powerful impact on public memory. Chatyn is the largest memorial to victims of the Nazi occupation in the post-Soviet space to be dedicated to civilian losses. A monopoly was held by the heroic partisan resistance. The memory of the Jewish Holocaust and the genocide of Roma were ignored in the Chatyń memorial. A monopoly was held by the heroic partisan resistance. As Vitali Silitski noted:

Mašeraŭ was an immensely popular and charismatic personality, a man who himself had been a guerrilla and was awarded the Hero of the Soviet Union star at the age of 26 . He is still revered by Belarusians for Belarus's unprecedented prosperity during the Brezhnev era. It was Mašeraŭ who transformed the partisan war into

2 Thus, one of the most respected experts on the history of the German occupation regime in Belarus Jury Turonak believes that the real number of civilian casualties amounted to 750 thousand people not to 1.4 million. He also argues that victims of the Stalinist repression of 1937-41 were deliberately included in the Soviet statistics of civilians perished. in the war (Turonak 2008, 678-83). 
a national myth and made it a trademark by which Belarus is still identified - at least in the former Soviet Union (Silitski 2005).

\section{Genocide and Soviet Memory Politics}

World War II was the biggest disaster ever experienced by the civilian population of Belarus. The ethnic Belarusian, Polish, Russian, Ukrainian, Tatar population of the republic suffered massive losses. Two minorities (Jews and Roma) suffered systematic physical annihilation by the Nazis. It should be pointed out that the mass killings of Jews and Roma, recognized as genocide by international community, differs in nature from the mass murder of other sectors of the Belarusian population. The notion of genocide has a strictly defined legal meaning. The key notion for a legal evaluation of the genocidal nature of mass crimes is intent. The latter means that legal theory treats differently dolus generalis and dolus specialis in cases of mass crimes against humanity. It means that a genocide did not occur when the mass murder of individual members of a group (dolus generalis) was not done with specific intent (dolus specialis) of exterminating the community as such (Schabas 2000, 213-25).

The slaughter of the civilian population by the Nazis was a crime against humanity, but do not fall within the accepted notion of genocide. So far, not a single document has been discovered that would give evidence of any plans of the Hitler regime to fully exterminate Belarusians as an ethnic group. Paradoxically, the occupation regime placed its stakes on Belarusian nationalism, and Belarusian collaborators had high chances of survival. In the first instance, those Belarusians who took part in the underground resistance movement or supported it became victims of the Nazis.

The terror against the rural Belarusian population during anti-partisan operations and the killing of members of the underground did not fall within the scope of the 'Convention on the Prevention and Punishment of the Crime of Genocide' because they were based on the temporary political or military objectives of the Nazi regime. Even the mass extermination of Belarusian civilians by the Nazis in 1944 near Azarycy (Homiel region) was driven by their attempt to stop the offensive of the Red Army. ${ }^{3}$ Despite the legal discrepancy, the qualification of mass crimes of the Nazis against the ethnic Belarusian population as genocide is popular in the discourse of the contemporary Belarusian memory politics, as we shall see later. Thus, the

3 On the basis of materials from German archives, historians Christoph Rass and René Rohrkamp demonstrated in their project that the mass extermination through exposure to typhus fever of 50 thousand Belarusian people driven together to the Azarycy death camps in Homiel region was a deliberate and systematic action of the Wehrmacht which was documented in details. The slaughter aimed at stalling the offensive of the Red Army at the cost of civilians' lives. This criminal policy attained its goal. In January 1944, for a week, soldiers of the Soviet 65th Army were busy with evacuating 33 thousand sick and weak people from the Azarycy camps. Among them, there were 15,960 children. 
collective trauma of the war is fixated on the country's titular nation.

The mass murder of the Jewish and Roma population was of an exceptional nature because the extermination of these ethnic groups took place with the specific goal of their total annihilation. But the exceptional nature of the Jewish and Roma Holocaust was denied by the Soviet government. This is why hundreds of mass graves of these groups were unmarked in Belarus. While keeping silent about the victims' actual ethnic origin, the authorities used the newly-created notion of 'peaceful citizens'. In 1963 a memorial on the site of the largest Holocaust death camp in the Soviet Union was opened in the village of Traścianiec in a suburb of Minsk. Despite all evidence to the contrary, the Soviet Belarusian authorities ignored the fact of the extermination of 65 thousand Jews here, and put the following inscription: 'On this site, near the village of Traścianiec, Nazi German invaders murdered, tortured and burned 201,500 individuals, peaceful civilians, partisans and Soviet POWs in 1941-44'. In the post-Soviet space, the difference between genocide and other mass crimes of the Nazis is still blurred.

During the Soviet era, the Nazi genocide of Jews and Roma was muted. The victory was achieved by all Soviet people, and the war was a tragedy for all Soviet peoples. The key note of Soviet memory politics was heroisation. For Soviet leaders, this war was first of all a war of heroes: soldiers, partisans and members of the underground resistance. The Soviet memory of war was full of taboos. Besides the Holocaust there were some issues of the chronology and geography of the war, crimes by Soviet partisans, the history of the non-Soviet (Ukrainian, Polish and Belarusian) partisan resistance, and the mass collaboration of Belarusians with the Nazi regime. For the Soviet people, World War II began in 1941 near Brest. Most Belarusians still do not know that the famous Brest fortress experienced two heroic defences in 1939 and 1941. In 1939, this fortress was defended by its Polish garrison from the Nazi army's offensive (Marples and Rudling 2009). Thus, the Soviet totalitarian regime kept silent over many aspects of the war.

\section{The Jewish Holocaust and Memory Politics in Post-War Belarus}

The 1939 census recorded 375.1 thousand Jews in Soviet Belarus (before its unification with Western Belarus). According to the Polish census of 1931, there were 283.3 thousand people of Jewish origin in the western Belarusian territories (Rozenblat and Elenskaia 2002). Thus, at the beginning of World War II, about 660 thousand Jews lived in Soviet Belarus. In 1939-41, this figure was increased by thousands of migrants from the German zone of occupation in Poland. The total number of Jews in the territory of Soviet Belarus by 1941 can be estimated at 820 thousand people (Törnquist-Plewa 2006, 46). The majority of Belarusian Jews were 
exterminated by the Nazis during the first (1941) and second (1942-43) waves of the Holocaust. The proper Belarusian victims of the genocide were joined by dozens of thousands of European Jews and Soviet POWs of Jewish origin exterminated on the territory of Belarus. Only those who fled to the partisans or those who were able to become refugees in June 1941, escaped this fate. ${ }^{4}$ These people and their descendants made up the 150-thousand-strong post-war Jewish Diaspora in Belarus.

There are different approaches regarding the role of ethnic Belarusians in the Holocaust (Kotljarchuk 2004 and 2007). Some scholars assert a sympathetic attitude by Belarusians to the Jewish population which was rather exceptional for Europe (Epstein 2004). Belarus ranks eighth in world for the number of people who, because of having saved Jews, became 'Righteous Among the Nations'. Other scholars speak about the active and massive participation of Belarusian collaborators in the Holocaust (Dean 2000, Rein 2011). In contemporary Belarusian historiography, the Holocaust is seen as a deed of the Nazis with some help from Latvian, Lithuanian and Ukrainian auxiliary police. Therefore the Holocaust and Belarusian collaboration are not linked (Törnquist-Plewa 2006, 47-49).

During the war, the Soviet media showed the extraordinary nature of the mass murder of Jews by the Nazis (Berkhoff 2010). The first monuments erected in 194447 openly stressed the ethnicity of genocide victims. According to this model the monument 'Jama' was built in Minsk in 1947 - the first urban monument in the Soviet Union which showed the Jewish origin of the victims. However, the '1953 Doctors' plot', followed by an anti-Semitic campaign put a stop to this temporary phenomenon. The victims of genocide turned into non-specific 'peaceful citizens'. But the tenacious struggle of the Jewish community for the preservation of memory led to a certain compromise. On many mass graves the texts about 'Soviet peaceful victims of Fascism' were reproduced in Yiddish language letters which left no doubt as to the ethnic origin of the victims (Altshuler 2002). This is how the memorial plate at the Jewish mass grave in Turaŭ looks where the text in Russian is accompanied by the text in Yiddish.

The history and commemoration of the Holocaust was uncomfortable for the Soviet government because it could become a starting point for the formation of a strong Jewish identity. For example the Minsk monument 'Jama' became a place for the annual memorial meetings of the Jewish community. The Soviet authorities placed emphasis on the heroic aspects of the war, marginalizing the tragedy of the genocide. The situation in the community of Belarusian Jews (as well as Roma and Poles, as we shall see later) at this time could be described as individual or family

4 In November 1941, the Central Inquiry Bureau of the USSR registered 222 thousand Jewish refugees from the BSSR (Smilovitskii 2010, 82). 
memory about the war without any chance for public remembrance.

According to Il'ia Altman, forgetting the Holocaust in the Soviet Union was, in practice, a form of its denial because it was based on the total inaccessibility of archives and punishment of those who tried to breach the wall of public silence (Altman 2001, 473-74). The foreign policy factor also played its own role, namely the hostile attitude of the Soviet Union towards Israel, and military and political cooperation with Arab countries. For example, in 1982, at the Institute of Oriental Studies of the Soviet Academy of Science, then headed by Evgenii Primakov, a dissertation entitled Links between Zionism and Nazism in 1939-1945 was successfully defended. The author was Mahmoud Abbas, now the president of the Palestinian Autonomy.

One of the instruments for maintaining silence on the Holocaust was the unfounded equating of the systematic extermination of the Jewish population to the mass killing of the Slavic population by the Nazis. For instance, speaking in 1965 at an international conference in Czechoslovakia, Soviet historians E. Boltin, F. Shevchenko and I. Kravchenko stated that 'the legal status of the Belarusians in Nazi-occupied Minsk was little different from the situation of the Jewish population of the city' (Leizirov 2006). The success of the politics of forgetting was impeded in Soviet Belarus by one factor. After the war, almost the entire territory of Belarus turned into a massive Jewish cemetery (Levin 2010, 174). This is why one of the directions of Soviet memory politics was to renounce identifying of the origin of the victims in mass graves and erection of the Holocaust monuments.

After the collapse of the Soviet Union, a process which can be described as the 'nationalization of the memory of World War II' started in Belarus as well as in other CIS countries. The annual military parade in Kyiv on Victory Day is inaugurated under the banners of the First and Second Ukrainian Fronts, and in Minsk, under the banners of the First and Second Belarusian Fronts. All this is despite the fact that the notion 'Ukrainian' or 'Belarusian Front' meant the direction of the offensive and did not have any national overtone. In Tashkent, the capital city of Uzbekistan, in 2010, a new memorial dedicated to the Uzbek soldier was built on the site of the memorial to the 'Soviet soldier' demolished by the authorities. In Ukraine, many monuments to the Ukrainian Insurgent Army (UPA) were erected. In Russian towns (for instance, in Voronezh), monuments to 'Russian soldiers of the Great Patriotic War' were erected.

Aliaksandr Lukašenka's state-building project is also based in great measure on the memory of World War II. According to Vitali Silitski, exploiting the mythology of World War II certainly has a practical political significance for Lukašenka. This is not only by claiming a special place for Lukašenka as the last defender in Europe of the glorious Soviet struggle against the Nazis, but also 
supporting the myth of the fight taken up by the entire Belarusian nation against the Nazi occupiers (Silitski 2005). The new Independence Day (3 July), the celebration of 9 May, a number of new memorials ('Stalin's Line'), blockbusters of the national cinema ('In August 1944' produced in 2000 or 'The Brest Fortress' produced in 2010) - all has a direct connection to the war. As during the Soviet era, huge memorials to war heroes are still being built in Belarus. The memorial 'Bujnicki Field' dedicated to the defence of Mahilioŭ in 1941 was opened in 1995. In 2005, the history and culture complex 'Stalin's Line' was opened on the site of a defence installations system built near Minsk alongside the western border of the Soviet Union in 1939. The memorial 'Stalin's Line' was dedicated to the 60th anniversary of victory in the Great Patriotic War with the support of the President of Belarus, Aliaksandr Lukašenka and financed by the charitable foundation of veterans of the Afghanistan war 'Afghan's Memory'. In 2004, the memorial complex 'Chatyn' was renovated in accordance with a decree of the president. Aliaksandr Lukašenka took part in a subbotnik - a voluntary clean-up of the memorial.

According to Andriy Portnov, the main strategy of integration of the memory of war in the new post-Soviet scheme is its 'humanization, that is the diversion of memory politics from heroes to the sufferings of ordinary people' (Portnov 2007). In Belarus, numerous monuments to war victims have been erected over the last ten years. For instance, in 2007, in the village of Krasny Bierah in the Homiel region a state memorial complex commemorating children who had died in 1941-44, was opened. In Belarus, this memorial has the nickname of 'Children's Chatyń'. Here, in 1942-43, there was a transit camp for young people who were sent to Germany. According to some witnesses, children who were held there were also used as blood donors for Nazi soldiers. The memorial was designed by a creative team headed by Lieanid Lievin, Merited Architect of Belarus and author of the Soviet memorial 'Chatyń'. 'Krasny Bierah' is the world's largest memorial dedicated to child victims of World War II.

Since 1991, the historiography of the Holocaust has been developing in Belarus (Rozenblat 2003). Memory politics, however, are still under-studied. Rethinking the Soviet mythology of the war created opportunities for the inclusion of the collective trauma of the Jewish minority into a national context. During Aliaksandr Lukašenka's presidency, dozens of new monuments dedicated to the Holocaust have been erected in Belarus. Among them, there are the new memorial 'Jama' in Minsk (2000), monuments to German (2008) and Austrian Jews victims of the Holocaust (2009) in Minsk, monuments in Valožyn, Viciebsk, Babrujsk, Barysaŭ, Baranavičy, Brest, Druja, Mahilioŭ, Hlusk, Niasviž, and Pinsk. In contrast to Soviet times, the Jewish origin of victims is emphasized on all monuments. According to the 
'Commission on the memorialization of the Holocaust victims', during the last five years, 45 new Holocaust monuments were built in Belarus with the support of the state (Shoŭkun 2010). In accordance with a decision by the Minsk City Executive Committee, a memorial complex will be built on the site of the former concentration camp of Traścianiec, the largest death camp on the territory of the Soviet Union and the fourth largest camp in the Nazi-occupied Europe.

In 2008, the 65th anniversary of the liquidation of the Minsk ghetto was commemorated at a governmental level by the State Organising Committee, headed by Lieanid Huliaka, the Minister for Religions and Nationalities Politics. Minister of Defence Lieanid Malcaŭ awarded a medal '60th Anniversary of Victory in the Great Patriotic War' to participants of the resistance movement in the Minsk ghetto. On 20 October 2008, in the presence of representatives of the Jewish community and the diplomatic corps, Aliaksandr Lukašenka visited for the first time the memorial 'Jama' (Lashkevich 2008). In his well-prepared speech, the president recalled the main events of the Holocaust, aid from the ethnic Belarusian population, and confirmed the decision of the government to build a new memorial in Traścianiec.

Exhibits in Belarusian museums are also changing gradually. For instance, the famous museum of the Brest Fortress now has information related to the Holocaust and the liquidation of the Brest ghetto (Ganzer and Paskovic 2010, 94). It is interesting that such a fundamental change in memory politics is being implemented by the current authoritarian regime. The huge project of memorializing the Holocaust supported by the Belarusian state is certainly of a positive nature because it contributes to tolerance and respect for minority rights. The opinion of some Belarusian researchers that a 'Soviet' canon of memory is frozen in Belarus seems doubtful (Lastovski 2009). The incident in Mazyr, where the local authorities edited in the Soviet spirit the inscription on the monument which was supposed to memorialize the Belarusian Jews, was an exception. However, soon after, more objective information appeared on the monument. ${ }^{5}$

At the same time the Belarusian authorities continue to adapt the concept of genocide to the mass extermination of the Slavic population. For instance, in his solemn address on the 60th anniversary of liberation of Belarus from the Nazis, Lukašenka again stressed the thesis of the genocide of ethnic Belarusians:

Moreover, Hitler's occupation was a particular phenomenon: the

\footnotetext{
5 In August 1941, more than 20 Jews from Mazyr set themselves on fire in protest against the Nazi genocide. In 2003, a monument was erected on the initiative of foreign Jewish organizations. The local authorities, however, removed the memorial sign, which was allegedly 'built without securing approval'. In 2010, the authorities reinstated the monument, having done it, however, in a specific way: in place of the inscription about Belarusian Jews there appeared a reference to an act of 'peaceful inhabitants of Mazyr' (Bratochkin 2012).
} 
German fascists contemplated exterminating the Belarusian nation. Berlin wanted to retain only a quarter of us, Belarusians, in the 'cleansed' living space, and only as slaves. During the three years of occupation, Hitler's forces exterminated our people with cynical orderliness. They shot and burned alive not only those who rose in arms but also children, women and the elderly (Lukashenka 2004).

The mass extermination of the ethnic Belarusian population is defined also as 'genocide' on the official web page of the state memorial 'Chatyń'.

New calculations of the number of victims have also emerged. The competition of Lukašenka with Mašeraŭ, the most popular Belarusian politician of the Soviet era, echoed not only in the changed name of a central avenue in the capital city, but also in memory politics. According to Lukašenka, not one in four but 'every third inhabitant of the republic' died in World War II (Lukashenka 2004). Despite the absence of reliable data for such a statement, this number has become canonical in contemporary Belarus.

The process of the memorialization of the Holocaust runs in parallel with the decline of the Jewish Diaspora. In 1989, there were about 112 thousand Jews in Belarus, 10 years later their numbers dropped to 27 thousand. During the last ten years, the size of the Jewish population has decreased by 56 percent and amounted to 12 thousand people in 2009 (Perepis 2011). This creates serious obstacles to future memorial activities because the local Jewish communities are active players in the area of memory. The active memorialization of the Holocaust confirms the conclusion of Sergei Ushakin that today a realignment of the memory of war around a new narrative axis is taking place in Belarus (Ushakin 2001,231).

\section{Roma of Belarus and the Memory of Genocide}

The census of 1939 counted 3,632 Roma in Soviet Belarus (Perepis 2011). At the same time, there were about 30 thousand Roma in inter-war Poland (Ficowski 1989). It is not known how many of them were nomads in the Eastern 'Belarusian' area of the Polish state. The census of 1959 counted 4,662 Roma in Soviet Belarus. Valdemar Kalinin, a Roma journalist and activist, believes that about 40 per cent of the prewar Roma population of Belarus were exterminated by the Nazis and their collaborators (Kalinin 2005, 100). German historian Christian Gerlach writes about 3,000 victims of the Nazi genocide of the Roma in Belarus (Gerlach 1999, 1063).

In 1944, leading Soviet newspapers stressed that the extermination of Roma by the Nazis was motivated exclusively by racial goals: 'they shot Roma only because they were Roma' (Soobshcheniia 1944). However, after the victory, the systematic 
extermination of the Roma population by the Nazis became a taboo and was ignored by Soviet historiography and historical politics. The absence of an educated strata within the Roma group and the aggressive forgetting politics made impossible the recording of testimonies of the Soviet Roma tragedy immediately after the war. Today it is simply impossible because of a lack of witnesses and archival records. Memory of the genocide was preserved mostly in an oral form amongst the Roma. The situation within the Roma group at that time could be described with the formula 'remembering without commemoration' (Stewart 2004).

There is only one known initiative in the Soviet era to erect a monument on the mass grave of Roma genocide. In 1968, artists of the Moscow state theatre 'Romen' applied to the Smolensk Region Executive Committee with a petition. The aim of their appeal was to authorise the construction of a monument on the site of the mass execution of 176 settled Roma killed in the village of Aleksandroŭka on 24 April 1942. A group of Muscovite intelligentsia, which included the renowned Roma artist Nicolay Slichenko, whose father and relatives were murdered in the genocide, V. Efremov, F. Kondenko, and the renowned translator and civil rights activist Lev Ginzburg launched this initiative. They met witnesses, gathered evidence of the tragedy, and offered to erect the monument at their own expense. But the authorities did not concede. When perestroika began in 1985, the theatre 'Romen' put on a play, 'Birds Need the Sky', inspired by the Smolensk mass murder (Holler 2008, 263-79). In 1991, a monument was finally erected on the site of the mass grave. The ethnic origin of the victims, however, was ignored. The text of the monument says shamefully that 'Here Lie 176 Dwellers of the Village of Aleksandroŭka Executed by German-Fascist Invaders on 24 April 1942'. At the same time, the struggle of the Jewish intelligentsia resulted in some compromise with the authorities. The text about 'peaceful Soviet citizens - victims of fascism' on many monuments was duplicated in Yiddish.

In recent years, about twenty monuments commemorating victims of the genocide of the Roma have been erected in Ukraine. According to decision № 2085-IV of the Ukrainian parliament dated 8 October 2004, the International Day of the Holocaust of the Roma is held annually on 2 August. Following the countries of the European Union, Ukraine abandoned the use of the word 'Gypsies' in favour of the more politically correct name 'Roma'. At the same time, in Belarusian mass media, the term 'Gypsy' is often associated with criminality, which turns them into a marginal group of society.

In Belarusian historiography, information about the genocide of the Roma is minimal. In neighbouring Ukraine, over the last few years, a number of conferences on the genocide of the Roma were held, collections of scientific papers were published, and research centres were formed. At the same time, in Belarus, not a 
single scholar specialises in this subject. And scholarly publications are restricted to a single article written by Germany-based historian Alexander Fridman (Fridman 2004). This is probably why the article 'Gypsy' in the Encyclopaedia of History of Belarus contains only a short reference to the extermination of the Roma, and specialized academic works on the history of the Belarusian Roma do not mention the tragedy of the Roma people at all (Dučyc 2003). As Mihajlo Tiahlyi points out, the mass extermination of the Roma is still seen by post-Soviet researchers as a 'second-rate genocide' and remains at the periphery of historical studies (Tiahlyi 2011).

Memorialization of the victims of the Nazi genocide of the Roma has a number of objective obstacles related to the Soviet period. The politics of forgetting and poor integration into Soviet society did not give the Roma an opportunity for public recognition of their tragedy in the Soviet Union. The Great Soviet Encyclopaedia informed its readers briefly that "in the years of World War II in 1939-45 about 20 thousand Roma were savagely exterminated by Hitler's forces in Central and Eastern Europe' (Ventsel' 1978). Thus, according to the Soviet encyclopaedia, the fact of the genocide of the Roma apparently had no relation to the Soviet Union. As a result, in 1991, there were no monuments with reference to or, at least, a hint of the genocide of the Roma.

One of the main problems of contemporary memory politics is the depersonalisation of the victims of the Roma genocide. The Roma traditionally avoid contact with the authorities, and the official data and the real number of the Roma can differ greatly. The Soviet census of 1939 did not take into account the Roma population of Western Belarus which merged with the Soviet Union at the end of 1939. As is well known, this territory was a traditional settlement area for the Belarusian Roma. The last pre-war Polish census of 1931 did not consider the Roma as a separate population group. Thus, the number of the Roma which lived in the summer of 1941 in the territory of today's Belarus cannot be calculated, even approximately.

We should also note that the majority of the Roma in Belarus led a nomadic life before the war. Usually, they had no passports, avoiding any registration. The villages of settled Roma were scattered as miniscule islands all over the territory of the republic (Harecki 1929). A part of nomadic Roma had to go into farming under Soviet pressure. In 1927, in Viciebsk district, the first Roma kolkhoz in the Soviet Union was organised (Dučyc 2003). We should also remember that Belarus was a traditional place of summer travels for Roma from Moldova and Russia. All this complicates calculations significantly. When nomadic non-Belarusian Roma are taken into account, the final number of victims can be greater. And all this, in turn, does not allow for the specification of even an approximate number of victims of the Nazi genocide. It is 
little known which Roma were murdered in Belarus in 1941-44.

Researchers of Romany history point out that a significant number of murdered nomadic Roma and the sites of their execution will remain unknown for ever. Often the only witnesses to these crimes were the murderers themselves (Bessonov and Demetr 2000, 217). For instance, in December 1966, the Homiel regional department of the KGB arrested former policemen of the 724th detachment of the secret field police (Gruppe Geheime Feldpolizei 724). The group operated in the territory of Eastern Belarus. During the investigation, the accomplices of the occupying powers showed an unknown site of execution of Roma in a wood near the village of Slabodka. In accordance with the KGB records, the execution of the Roma happened in the following way:

In the summer of 1942, returning from an anti-partisan action, the policemen saw a Roma encampment in a wood on the bank of a small river, and surrounded it. The Roma did not perceive any danger and were sitting serenely around a bonfire, cooking food and talking peacefully. The next day, the policemen, on a German order, took the Roma outside the village of Slabada to woods near the river Ula where a grave had been prepared in advance. There they executed without pity the entire encampment, including small children (Bachurin 2013).

It is important to stress a number of factors which differentiate memory work on the Jewish and Roma tragedies. Unlike the Jews, the Roma practically lacked their own cultural landscape. If today the Holocaust is remembered not only through monuments but also through deserted synagogues, the former Jewish ghettos and cemeteries, the Roma do not have any of these. With the genocide, almost all their physical space of memory was destroyed.

The Belarusian Roma have names and surnames which are typical for the local population (Belarusian or Polish). The role of anthroponymy is important. When the protocols of the Soviet Extraordinary State Commission (ChGK) do not mention directly the ethnic origin of the victims, it is possible to identify Jewish origins by analysing names. Thus, it is not possible to investigate the Roma origin of victims by analysing names. In most cases, the Belarusian Roma were executed at sites, which were chosen by the Nazis for the extermination of the Jewish population. Such sites were usually classified by the Extraordinary State Commission and marked by Soviet memorial signs. All of them, however, ignored the Roma victims of genocide.

Unlike the Belarusian Jews, the Roma are not a homogenous ethnic group. The Roma community of Belarus is divided into a number of dialectic and subcultural groups, among which are Bielaruska Roma, Lipiency, Biezancy, Pinčuki, Polska 
Roma-Feldytka, Siaki, Mukany, Bierniki, etc. Different groups profess Orthodoxy, Catholicism or Protestantism. As a result, relations between separate groups are not always close. From this a number of important conclusions may be drawn. Often there is no direct emotional (family) connection between the victims of mass burials and a local Roma community. This is what happened, for example, in the town of Turaŭ. During the war, near the swamp of Kazarhac, an unknown group of Roma was executed.

The present-day Roma community is represented by the Roma who are heirs to migrants of the 1950s who settled in this town after the decree by the Soviet government regarding a settled lifestyle. ${ }^{6}$ The Roma of Turaŭ are aware of the mass extermination of their ancestors by the Nazis, but do not know anything specific about the local mass grave. ${ }^{7}$ This is a typical situation. Depersonalization of the victims, together with a lack of research centres, mean that the Roma themselves are unlikely to be active agents of memory. In contrast to the Jewish community, initiatives to erect monuments in Belarus come mostly from the state and non-Roma NGOs.

Despite these problems, the memory politics of the genocide of the Roma in Belarus does not look like a failure, especially against the backdrop of Russia, where not a single Roma monument exists. In Belarus, in recent times, three monuments dedicated to the tragedy of the Roma were erected. The monument in Pinsk evokes the Roma together with the Jews and other victims of Nazism. The monument in the village of Haradzišča near Baranavičy is set in the Romany traditional style and has an emotional inscription in the Roma and Belarusian languages: 'Here Lie Our Brothers Roma Executed by the Fascists in the Summer of 1941 '. In 2008 victims of the genocide of the Roma were in a special way commemorated in the monuments of the Kaldyčava memorial. There is an interesting initiative by the Union of the Belarusian Jewish public associations and communities to erect in Minsk a monument to the Roma who died during World War II. With its three Roma Holocaust memorials Belarus occupies second place in the post-Soviet space after Ukraine. But dozens of Roma Holocaust mass graves in Belarus have remained unmarked and are in need of elementary preservation and commemoration.

Because of the absence of their own country, territory and common religion, the memory of genocide has the potential to unite different groups of Roma, mobilizing their national movement. As Sławomir Kapralski notes:

6 On 5 October 1956, an edict of the Presidium of the Supreme Soviet of the USSR 'On Engagement in Work of Nomadic Gypsies' was published. The edict provided for criminal prosecution of those who continued to be vagabonds. Police had an obligation to stop and register all camping Roma. The local authorities had an obligation to provide Roma with housing and jobs.

7 Materials of field studies of the author in June 2011, Turaŭ 
The Romany Holocaust is already the main element of Roma identity and the centerpiece of their historical memory. Through the rituals of remembrance Roma focus on their common past in order to create a better future (Kapralski 2012, 77).

For a long time the Roma minority did not share in the building of the Belarusian nation. The memory of the Roma Holocaust has the possibility of changing this situation, boosting the inclusion of Roma in contemporary Belarusian society. But the controversial battles over commemoration of the genocide make this process much more complicated.

\section{The Polish Minority and their Collective Trauma}

World War II was a catastrophe in the history of the Polish minority in Belarus. ${ }^{8}$ As a result of Hitler's and Stalin's aggression in 1939, the Poles of Belarus lost their own state and turned from a titular nation of the Second Polish republic into a stigmatized minority of the Soviet Union. As is well known, a policy of discrimination against the Belarusian minority was carried out in the inter-war Polish state (Lubachko 1972). As Nicholas Vakar pointed out, 'World War II found West Belorussians' loyalties divided between Communism and nationalism - but none whatsoever for Poland' (Vakar 1956, 136). The ethnic Poles who were at the top of the social hierarchy (most officials, military men, colonists and descendants of the gentry in Belarus) became the main target of Soviet repression in 1939-41 (Hryboŭski 2007).

The pre-war tension provoked a conflict between Belarusians and Poles on the territory of Nazi-occupied Belarus. This conflict gradually began to resemble a civil war (Chiari 1998, Hryboŭski 2006). Detachments of the Armia Krajowa (AK) which fought in Belarus against the Nazis, for the restoration of the Polish state, killed Belarusian activists. As has been mentioned, the Nazi administration placed its stake on Belarusian nationalism. Belarusian collaborators, using Germans or with the direct participation of local auxiliary police, killed Polish partisans, activists and Catholic priests. After the revelation of the truth about the Katyn Massacre and the rupture of relations between the Polish government in London and the Stalin government, the AK became an enemy of the Soviet Union. By the order of Kanstancin Panamarenka, First Secretary of the Communist Party of Belarus and Head of the Central Partisan HQ in Moscow, all Soviet partisans had to fight against the Polish AK.

8 Hereafter, by the word 'Poles' the author understands people who consistently stress their Polish ethnicity during numerous censuses and in their daily life. As is known, a considerable part of the Belarusian Poles do not have a good command of the literary language and are descendants of the autochthonous Catholic population of Belarus. 
After the war, the Belarusian Poles, despite their struggle against the Nazism, ended up among the defeated nations. About 275 thousand ethnic Poles between 1944-59 escaped from Belarus to Poland (Czerniakiewicz 2004). Even after this mass resettlement, the Poles were still the second largest minority in Belarus after the Russians (538.8 thousand according to the 1959 census). But unlike the Russians, the Poles lived in a compact way in Hrodna, Brest, Viciebsk and Minsk regions, and had well-developed cultural and religious institutions established in the pre-war period.

The Polish population suffered discrimination in post-war Belarus. The Poles and Germans were the only large Diaspora groups of the Soviet Union who did not regain their own autonomy after the war. The Soviet Poles lived compactly on the territory of western Belarus and north-eastern Lithuania. Whereas in Lithuania the Poles were able to develop their own system of education, cultural and religious communities, all Polish schools in Belarus were closed down. Institutionalised forms of the life of the Roman Catholic Church in Belarus also virtually ceased to exist. The selling of Polish newspapers and books was significantly restricted. As a result of the Soviet assimilation project, the Poles of Belarus, after being a nation with a strong educated elite, became a mostly rural, poorly-educated minority. All public Polish memorial ceremonies, such as the celebration of the Constitution of 3rd of May or the Independence Day on the 11th of November, became taboo. In these harsh conditions, memories of the Belarusian Poles about their past did not go outside family circles. Prior to 1991, not a single memorial to the Polish victims of World War II existed in Belarus. The Soviet authorities knew perfectly well that a memorial site could become a starting point for the mobilization of a Polish movement.

The situation began to change in the 1990s. It was an important issue, because the Poles are still the second largest minority in Belarus (294.5 thousand according to the census of 2009). Moreover, taking into account the compact nature of their settlement, the Poles are the most visible ethnic group of the country after Belarusians. ${ }^{9}$ On 16 June 1944, Jan Piwnik 'Ponury', commander of a partisan detachment of the Armia Krajowa was killed in combat with the Germans near the village of Bahdany in the Hrodna region. In 1988, his body was exhumed and transferred to Poland. In the early 1990s, dwellers of Bahdany succeeded in erecting a monument on the site of his death after a serious stand-off with the local authorities. The authorities did not agree with mentioning the name of the commander on the memorial tablet, which would have shown that the monument

9 The census of 2009 showed that Belarus had three large ethnic minorities which counted more than 100 thousand people: Russians (about 785 thousand), Poles (about 295 thousand) and Ukrainians (about 159 thousand). The fourth biggest minority (Jews) counted 13 thousand people only. All ethnic groups are disseminated throughout the entire territory of Belarus and only the Polish minority lives densely, which is a serious factor in the geographic and cultural landscape of Belarus. 
commemorated Poles who fought against the German-Fascist invaders. An unauthorized inscription in Polish was painted on the monument later: 'Here Died Jan Piwnik "Ponury", a Polish Partisan' ${ }^{10}$

Most of the 'Polish' monuments to the victims of World War II were erected during the presidency of Lukašenka. A comparative analysis of them demonstrates several trends in contemporary memory politics. The Belarusian authorities do not ignore references to the extermination of the Polish population by the Nazis. This is how information is presented on the monuments erected in the town of Hlybokaje, the village of Navumavičy in Hrodna district and Sitnica in Luniniec district. At the same time, any references to the participation of Belarusian collaborators in the killing of the Polish population are blocked.

In the meantime, inscriptions on the monuments to Polish victims of the Soviet regime say nothing about the perpetrators of the crime. This is how the memorial stone in Baranavičy (with a serious error in its Belarusian language usage) or the grave monument of Reverend Bolesław Korn in Masty, murdered by Soviet soldiers on 23 September 1939, look like. In many such cases, only chronological information on the monuments can serve as a hint. The year of 1939 in Polish collective trauma is associated with Soviet terror. This is the message of the inscription on the memorial cross in Baranavičy or the memorial stone in the military cemetery in Hrodna. On the contrary, in the Belarusian collective memory this year is associated with a positive event - the reunification of Western Belarus. ${ }^{11}$

The subject of the Soviet terror against the Polish population is still muted. The only known exception is the memorial tablet in the Roman Catholic church of St. Barbara in Lida commemorating soldiers of the Armia Krajowa. The tablet with an inscription in Polish remembers the inhabitants of Lida district - victims of Stalinist totalitarianism. And all this despite the fact that the Polish parliament adopted two declarations in 2009 and 2012 on the mass terror against ethnic Poles in the Soviet Union. As is well known, during the Great Terror the NKVD started a special Polish operation and murdered 111,091 ethnic Poles or persons related to Poland. Among the victims of the Polish operation were 17,772 citizens of Soviet Belarus (Petrov and Roginskii 1997). The declaration of 2012 dedicated to the 75th anniversary of the beginning of the 'Polish operation' includes an appeal to post-Soviet historians to research this dark page of the past (Uchwała 2012).

${ }^{10}$ An electronic letter from the Belarusian correspondent of Gazeta Wyborcza Andrzej Poczobut to the author of the article (20 November 2012).

11 There was never any 'reunification' of Soviet Belarus with Western Belarus in 1939, because the latter never belonged to the Belarusian SSR. Rather, change occurred with the Soviet occupation of Eastern Poland. As is well known, in 1939, according to the Molotov-Ribbentrop pact, Western Belarus was annexed to the Soviet Union while Hitler started World War II by occupying Poland. The Soviet 'liberation' put Western Belarus in a situation similar to that of the Belarusian SSR with its waves of Stalinist purges (Gross 1988). 
Between July and December 2012, a fierce discussion developed in the public space of the independent media of Belarus about the installation of a monument to soldiers of the Polish Army at Kurapaty. Kurapaty (today within Minsk) is the largest site of Soviet mass executions in Belarus. On 29 October 2012, activists of the NGO 'Memorial' erected a sign in memory of officers of the Polish Army murdered by the NKVD in Belarus with the inscription: 'A monument to officers of the Polish Army murdered by the NKVD in 1940-1941 will be erected here'. One of the initiators of the memorialisation of the Belarusian Katýn list is Ihar Kuźniacoŭ, a renowned researcher of the Soviet terror, an associate professor at Belarusian State University. However, soon afterwards, this sign was destroyed by unknown persons. On 29 November, members of 'Memorial' installed the monument again - a memorial cross with the inscription: 'To the Memory of Officers of the Polish Army Murdered in Belarus by the NKVD in 1940-1941' (Radio Liberty 2012). Leaders of the conservative opposition made a stance against the Polish monument in the pantheon of Belarusian trauma. At the same time, the official mass media ignored this story. In his address, the leader of the Belarusian Popular Front Zianon Paźniak described the erection of the Polish monument in Kurapaty in the following way:

As the discoverer, researcher and head of the archaeological study of Kurapaty in 1988, I state that, as of today, there are absolutely no grounds and absolutely no archaeological evidence which would provide a pretext for assuming that in Kurapaty 'officers of the Polish Army were executed' (or whatever military men from whichever army). Here, we have found the dead bodies of civilians only, and mostly of poor villagers in rubber overshoes and glued rubber shoe covers (Paźniak 2012a).

At the Party's congress in Vilnius, Zianon Paźniak again pointed out that Kurapaty was a pantheon of the Belarusian tragedy, and that other memory projects did not belong there:

... Neither archival documents nor archaeological studies have confirmed that they (the Katyn group) were executed and buried in Kurapaty. The site of their extermination is yet unknown and could be anywhere - nobody knows where. Therefore, no one should engage in adventurism and link abstract opinions to a specific site. It could be in a totally different place. These things should be dealt with seriously... Ultimately, the fatal blow of manslaughter was delivered on the Belarusian nation (and not others), because the Belarusians have no other place on Earth besides Belarus. In the 1930s-40s, the targeted genocide of the Belarusian nation was implemented by Russian Bolsheviks... (Paźniak 2012b). 
The assertion of Zianon Paźniak about the exclusively 'Belarusian' and mostly peasant nature of the victims of the tragedy at Kurapaty has a contradictory and political nature. At present, only 4 per cent of the mass graves has been excavated at Kurapaty. Due to the inaccessibility of the KGB archives, the names of the victims of Kurapaty remain unknown, which gives rise to different interpretations. During the selective exhumation in 1988 at Kurapaty under the leadership of Zianon Paźniak, the belongings of citizens of Baltic countries were found, and this fact indicates indirectly that foreigners were also murdered there, and that executions took place in 1940-41 (Paźniak and Šmahaloŭ 1994, 99-101).

This last circumstance coincides chronologically with the Katyn tragedy. In 1997-98, the military prosecutor's office of Belarus conducted a partial exhumation: nine more graves were excavated. In one of them, they found stars from the peaked caps of soldiers of the Red Army, straps, and Soviet overcoats, i.e. the remains of officers and soldiers of the Red Army. In a grave opened in 2009, the remains of a military man of one of the Baltic countries were found. This means that, contrary to the statement made by Paźniak, the extermination of military men took place in Kurapaty. Actually, a large secret police area in Kurapaty near the borders with the Baltic states and Poland was well suited for such mass executions.

Historians studying the Great Terror know that peasants were not the primary target of the Great Terror (Kotljarchuk 2012). Moreover, during the special national operations of the NKVD in 1937-38, first of all, Belarusian peasants of Polish and Latvian origin were exterminated in Belarus (Platonaŭ and Staškievič 1993, Morris 2004). Therefore the main peasant victims of the Great Terror in Belarus were people who had strong ties to the Roman Catholic Church and Polish culture. The main victims of repression against the rural population of 1939-41 were inhabitants of Western Belarus, often heads of communes or colonists of Polish origin.

The memory of Kurapaty and Katyń must unite and not divide the ethnic groups of today's Belarus. It seems that the memory of Kurapaty and Katyń is the most problematic for current leadership of Belarus and Belarusian society. The country's leaders have declared on many occasions that Belarus allegedly did not have archival sources regarding the execution of Polish POWs in 1940 in Belarus. At the same time, researchers affirm that the so-called Belarusian Katyn list exists and thousands of Polish victims were exterminated in Belarus (Mikulievič 2011).

As Per Anders Rudling points out, the Polish request made in 2009 to the Belarusian authorities for an investigation of a recently discovered mass grave of twenty to thirty people in the basement of the Catholic church in Hlybokaje, which Polish officials believe contains the bodies of Polish citizens killed by the NKVD, was met with silence. Neither the local nor the central authorities have been willing to comment on the issue. Michail Kuźmič, the director of the ideology department 
of the Viciebsk region, dismissed the Polish inquiries: 'This all regards distant history. How are we supposed to comment on something from a bygone era - an era from which there soon will be no survivors?' (Rudling 2012, 46). It is not by chance that not a single memorial sign dedicated to the Katyń tragedy exists in Belarus while there are plenty of them in neighbouring Poland. And this is despite the fact that a great number of the Polish victims of the Katyń massacre were of Belarusian origin. Among them, there were not only ethnic Poles from Belarus, but also ethnic Belarusians Jews and Tatars. For the same reason, citizens of Belarus - former soldiers of the Polish Army and the Armia Krajowa - were not given the status of war veterans.

In 2008, in accordance with a decision by the government of Belarus, the first and only memorial complex in the country dedicated to Polish, Jewish and Roma victims of World War II was built near the village of Kaldyčava in Baranavičy district. The prisoners of the Kaldyčava camp (mostly Polish partisans, priests and intelligentsia) were exterminated by soldiers of the 13th Belarusian battalion of auxiliary police (Weissruthenische-Polizei (SD)-Bataillon $\mathrm{nr}$ 13) which used national symbols, had Belarusian as the language of command and followed orders of the collaborationist administration of Minsk. A number of former policemen of Kaldyčava who were not able to escape to the West were arrested after the war in Poland and the Soviet Union and convicted for crimes by military tribunals in Wroclaw in 1957 and Minsk in 1962 (Sherman 1997). On the one hand, the Kaldyčava memorial reflects the contemporary 'non-Soviet' narrative of state memory politics. The ethnicity of victims has been stressed. The inscriptions in the official Belarusian and Russian languages are duplicated in the languages of the victims (Roma, Jewish and Polish). On the other hand, the memorial demonstrates the shortcomings of Belarusian memory politics. There are no texts which refer to Belarusian collaboration with Hitler's regime and the role of the 13th battalion in the extermination of the prisoners of the Kaldyčava camp. All blame is cast on the German occupiers. The inscriptions are made in a slovenly way, with gross mistakes: 'Союз белорусских еврейсов; 'Память замучаным в Колдычеве'; 'Семьи с Беларуси'. The last circumstance bears evidence of the marginal level of respect on the part of the memorial's authors for national minorities.

With the help of popular writers and the memoirs of émigré authors, today, some war criminals of Belarusian origin have become heroic fighters for independent Belarus. At the same time, Lukašenka placed his stake on the Soviet concept of a nationwide struggle against Nazism, disputing the fact of mass collaboration by Belarusians. Speaking in 2010 at a ceremonial meeting dedicated to the 65th anniversary of victory in the war, the head of the Belarusian state said:

Recently, one could hear preposterous statements that, allegedly, Belarus did not fight against Fascism but for its independence from 
other sisterly Soviet republics. And that, during the occupation, we were almost in the middle of a civil war and half of Belarus enrolled to work as police or served the Germans. Our principal position of principle remains unchanged. The Great Victory is sacrosanct for every Belarusian... And even if a bunch of such rogues exist (and we cannot name them in any other way), who like the idea of 'an independent Belarus in the new Europe of Adolph Hitler', we know them. We know in whose service their idols were during the Great Patriotic War, and we fully understand whose lackeys they are now (Lukashenka 2010).

The small number of Polish memorial sites of World War II and their marginal nature (the absence of a memorial in the capital, their remote locations) can probably be explained by the current politics of the Belarusian government. The problematic relationship between Belarus and Poland, the division of the Union of Poles in Belarus masterminded by the Minsk authorities, and a historical mistrust of Poles by Belarusians reflect the slowdown of the memorialization of Polish memory sites.

\section{Conclusion}

Contemporary trends in the memory politics of World War II in Belarus can be summed up well by comparison with the processes in Ukraine and Russia. Today, in Ukraine a step has been made towards mitigation of the conflict of 1943 between Ukraine and Poland. This step was upheld at the state level. On 11 July 2003, the presidents of Poland and Ukraine, Aleksander Kwaśniewski and Leonid Kuchma took part in a ceremony in the village of Pavlivka (the Polish name is Poryck) in Volhynia where they inaugurated the first monument of reconciliation. Since then, a number of Polish memorials have been erected in Ukraine. At the same time, the Belarusian authorities sidestep or slur the Belarusian-Polish conflict in wartime. It would seem that the main reason for this is a desire to avoid any public discussion about the mass nature of Belarusian collaboration, which is unavoidable in this case.

The activities of Ukrainian nationalists and detachments of the Ukrainian Insurgent Army (UPA) in Belarusian Polessie are marginalized in the public discourse of Belarus. While several monuments to soldiers of the UPA were built in the territories of neighbouring Luck and Žytomyr regions, not a single 'Ukrainian' memorial of World War II exists in Belarus. And this is despite the existence of 160thousand-strong Ukrainian diaspora in the country. In November 2012, the Belarusian authorities forbade the inauguration of the first memorial tablet honouring the UPA in the village of Dzivin in the Kobryn district. The first detachment of the UPA was created in that very place in October 1942. In their negative reply, officials 
from Brest pointed out that honouring the UPA did not fit into 'the memorialization of important historical and social events of national history, renowned state, political, civic and military figures and national heroes' (Hiezhala 2012).

In the meantime, dozens of Russian monuments to the war of 1812 and World War I are being re-established which, according to the authorities, have direct relation to national history and heroes. In August 2011, an inauguration ceremony for a memorial to soldiers of the Russian Imperial Army, built after an edict by Lukašenka, was held in Minsk at the state level. It would seem that by implementing such politics, the Belarusian authorities deliberately do not distinguish between representatives of Russian and Belarusian ethnicities. One of the reasons for such an approach is the assimilative politics of the government. A potential objective of the authorities is a merger of the Belarusian and Russian ethnicities into a single Russian-speaking community in Belarus. Statistics reflect the first results of such politics. How else can the fact that the number of the ethnic Russian population in Belarus decreased by a third (32 per cent) over ten years (1999-2009) be explained? At the same time, there is no evidence of a mass emigration of Russian people from Belarus to the Russian Federation.

Finally, it is interesting to stress some similarities in the memory policies in Belarus and Russia. As in Russia, the memorialization of the genocide of the Roma in Belarus progresses slowly. At the same time, the problems related to commemoration of the genocide of the Roma on the territory of Belarus, as this article has demonstrated, are limited by 'path dependence' and not by deliberately discriminatory politics towards the Roma population. On the contrary, the memorialization of the Holocaust in Belarus, as in Russia, is progressing at a swift rate. During recent years, a number of new monuments have been built in Russia, and two big museums dedicated to the Holocaust opened in Moscow (Holocaust Memorial Synagogue opened in 1998 and Jewish Museum opened in 2012). In 2002, the Museum of Jewish History and Culture of Belarus was inaugurated in Minsk which includes an exhibition about the Holocaust.

Fast-paced memorialization of the genocide of the Jews confirms the fact that the realignment of Soviet history around new narrative axes is taking place in the historical politics of today's Belarus. In the classification of Jeffrey Blutinger, Belarus, together with other countries of Central and Eastern Europe, belongs to the second stage of 'deflective negationism', which means that the Holocaust is recognized, but all responsibility is placed exclusively on the Germans. It is worth noting that in contrast to the Soviet era, memory politics in Belarus are being built on the basis of a pan-European concept of reconciliation.

The revising of the Soviet myth of World War II opened the closed floodgates of memory. This regards the memory of the Holocaust, the genocide of the Roma, and 
the Polish collective war trauma. The next topics for heated debate on World War II in Belarus may be the Belarusian-Polish conflict, the activities of the Ukrainian Insurgent Army, the crimes of Soviet partisans, the participation of Belarusian collaborators in the Holocaust, and the Stalinist deportations of 1939-41. 

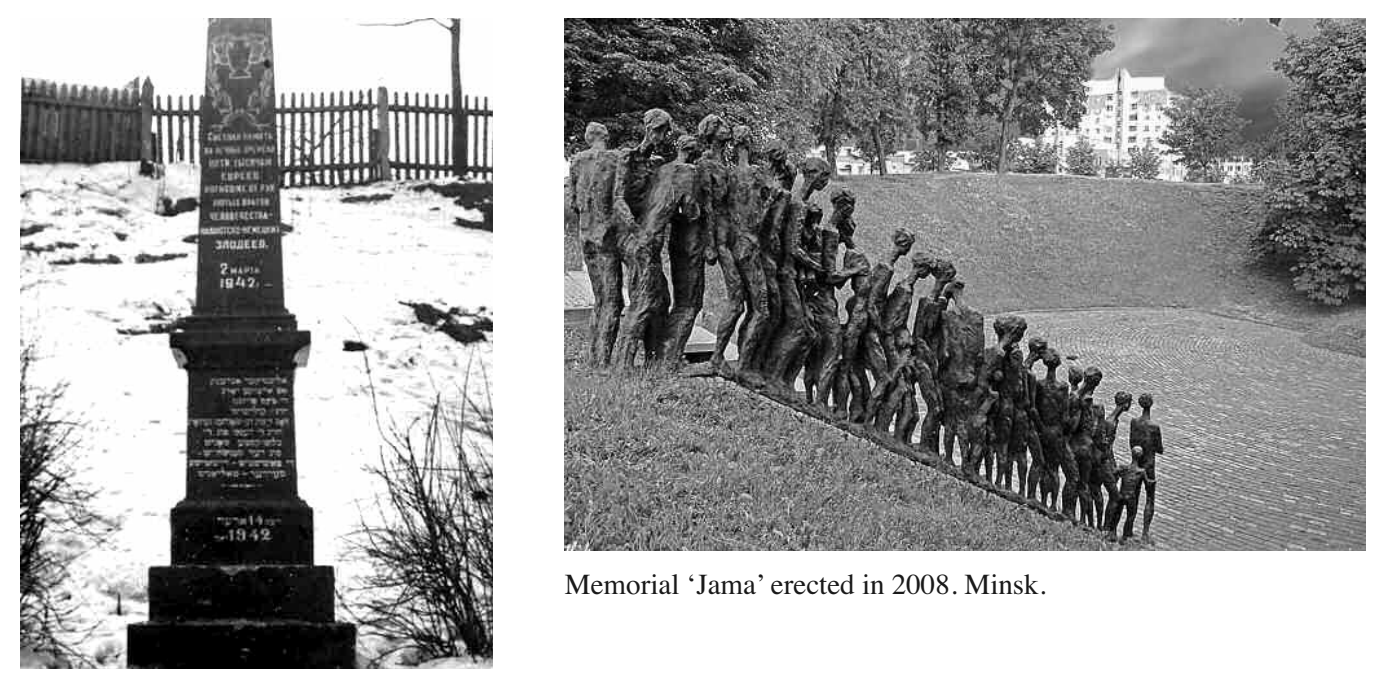

Memorial 'Jama' erected in 2008. Minsk.

Memorial Holocaust Stone erected in

1947 in 'Jama'. Minsk.

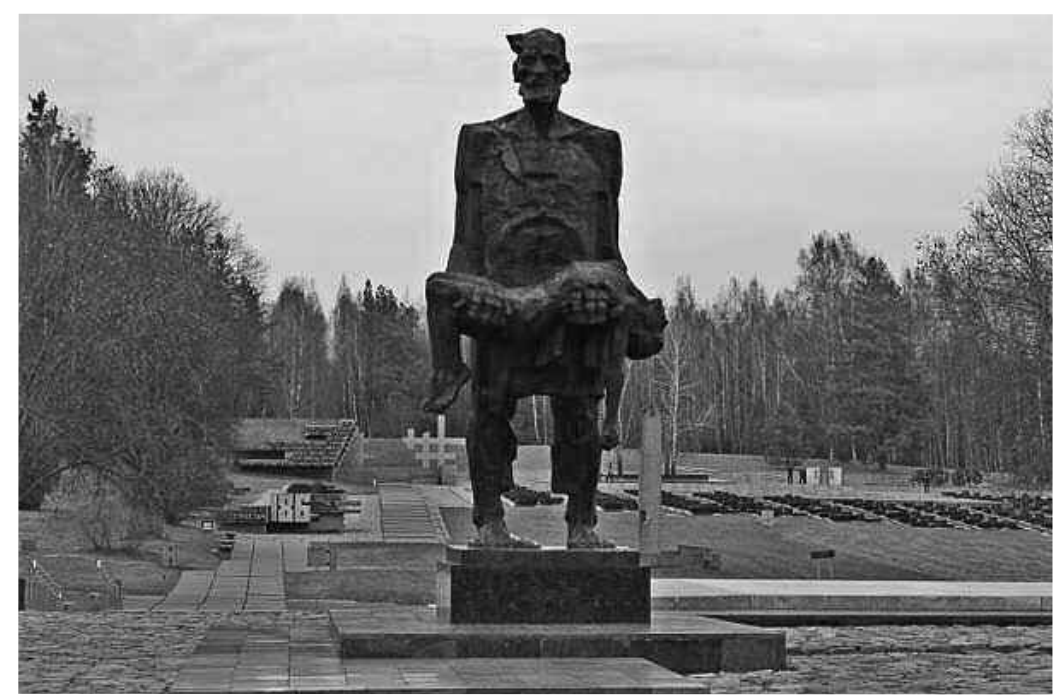

Memorial complex

"Chatyńn". "The

Unconquered Man" -

a tribute to Joseph

Kaminsky and his son.
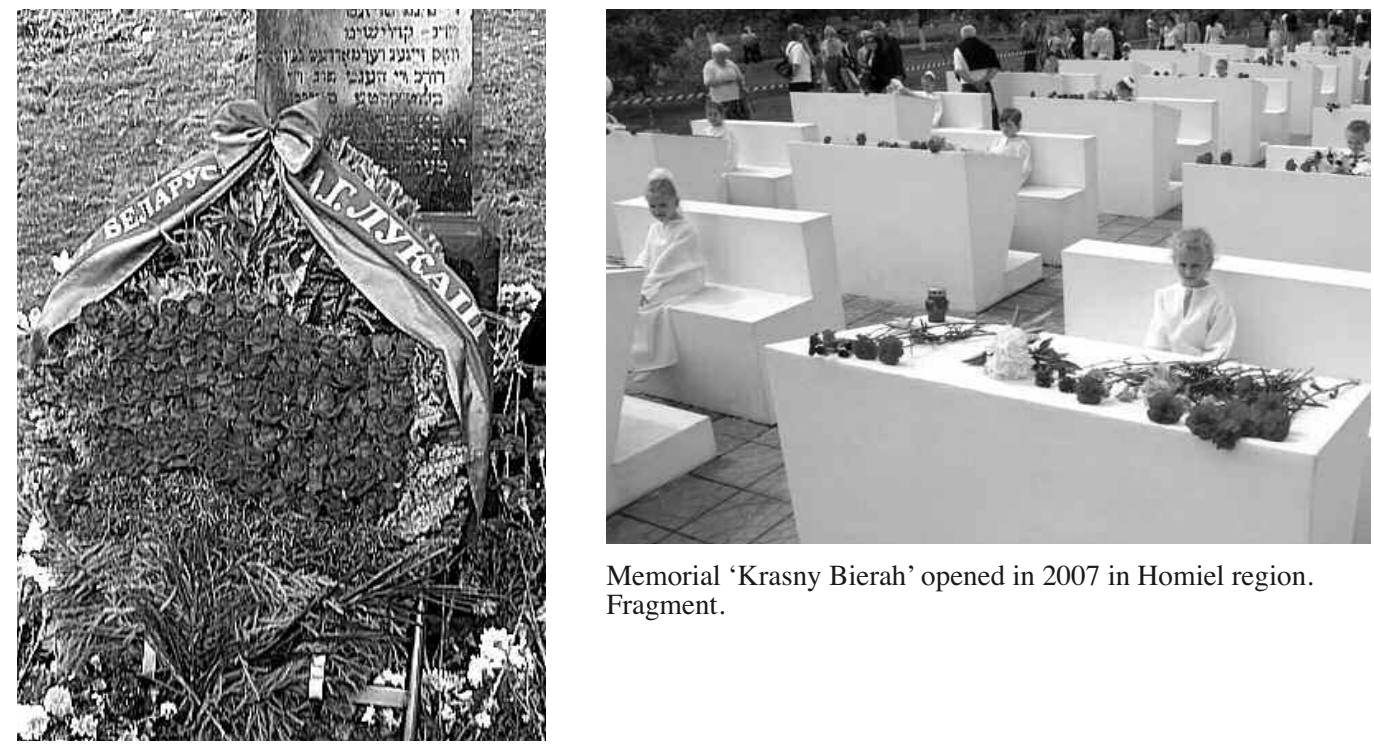

Memorial ‘Krasny Bierah' opened in 2007 in Homiel region. Fragment.

Memorial Wreath from President Aliaksandr Lukašenka to the commemoration of the victims of Holocaust in Belarus. 


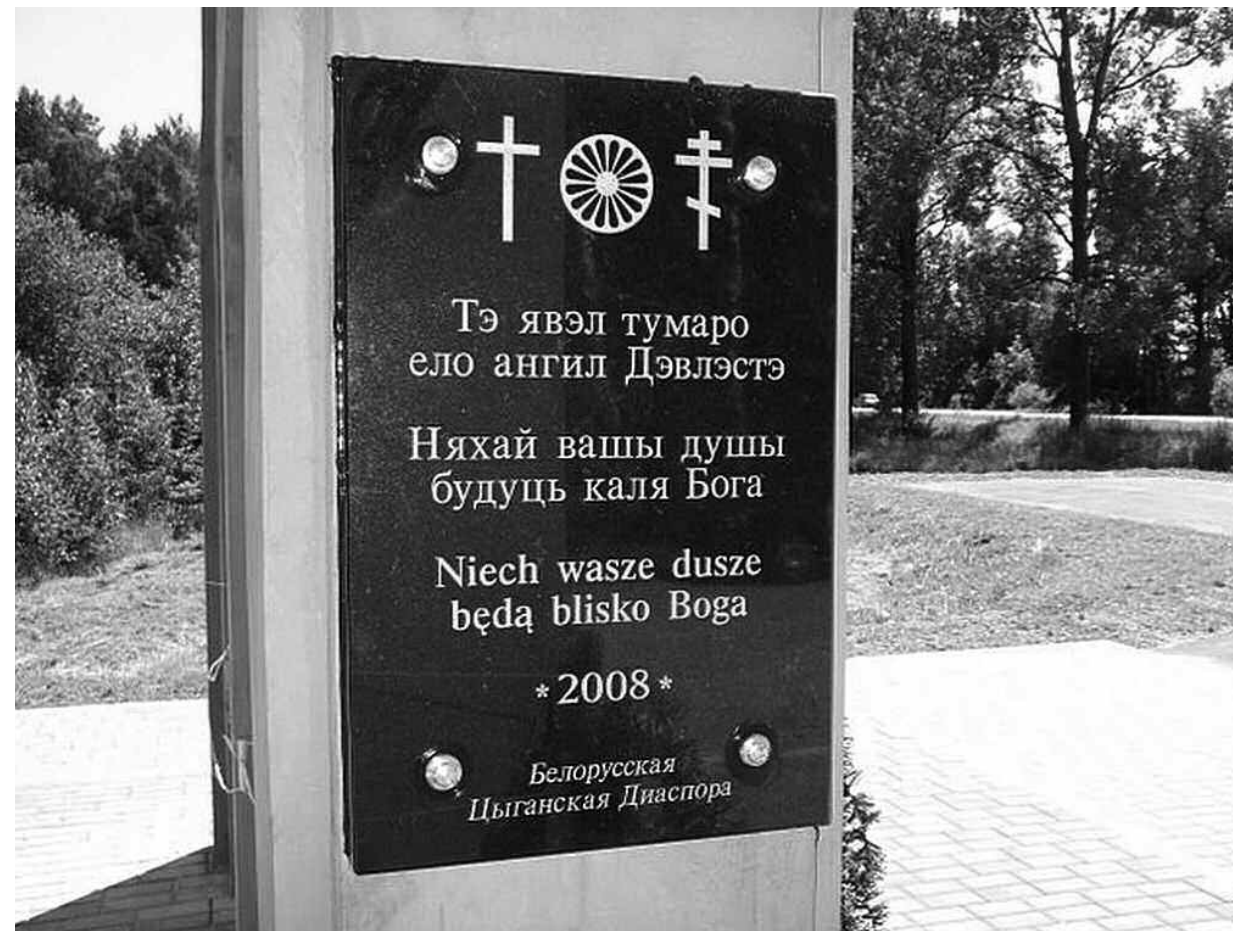

Roma Memorial in Kaldyčava. Baranavičy district.
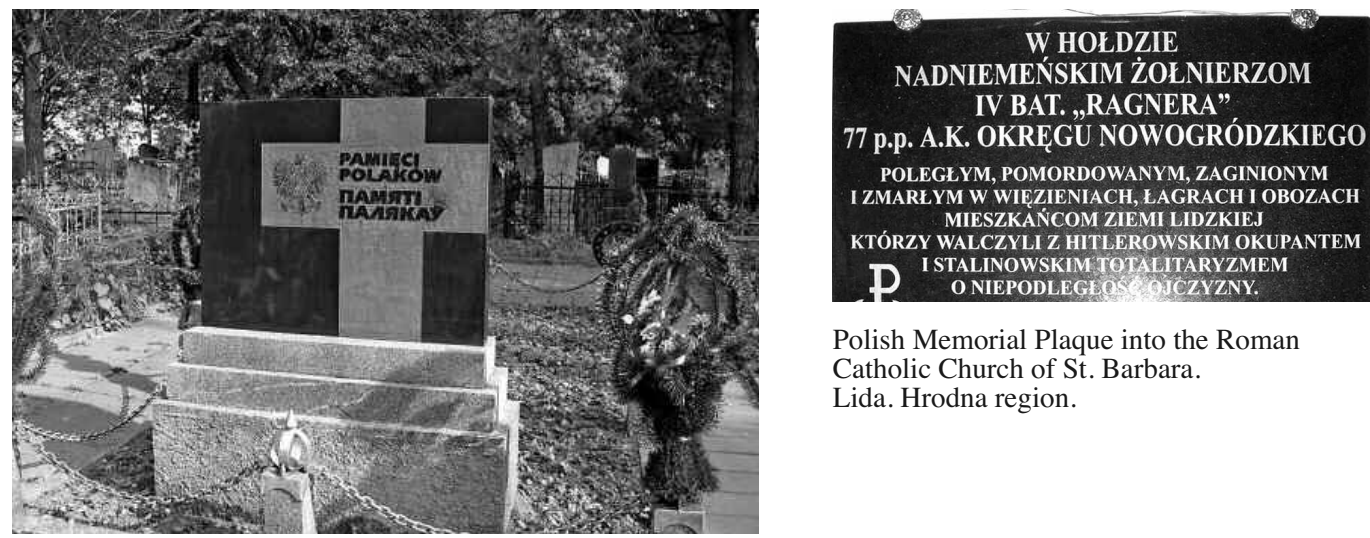

Polish Memorial Plaque into the Roman Catholic Church of St. Barbara.

Lida. Hrodna region.

Polish Monument in Baranavičy.

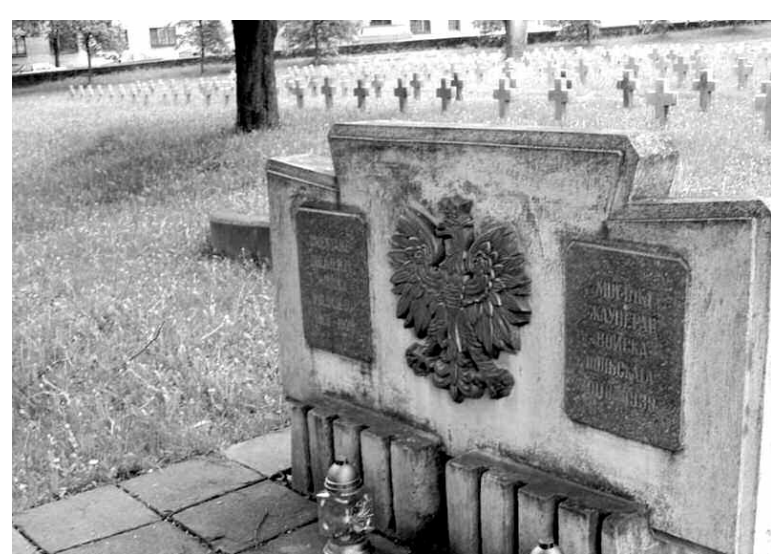

Polish Monument at Hrodna cemetery.

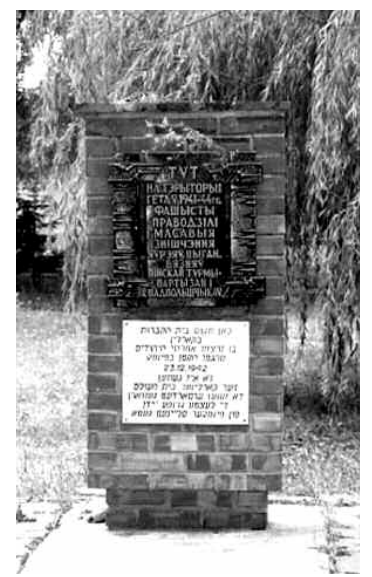

Roma and Jewish Holocaust Monument in Pinsk. 


\section{References}

Altman, Il'ia, 2001. Otritsanie Kholokosta. Istoriia i sovremennye tendentsii, Moskva: Fond 'Holokost', Zhurnalistskoe izdatel'stkoe agentstvo 'ZhAG-VM'.

Altshuler, Mordechai, 2002. 'Jewish Holocaust Commemoration Activity in the USSR under Stalin', Yad Vashem Studies, 30, pp. 221-40.

Bachurin, L. V., Pered sudom pamiati $i$ sovesti, <http://www.penza.fsb.ru/content/history/veterans2.html>. [accessed 28 January 2013].

Baer, Ulrich, 2000. 'To Give Memory a Place: Holocaust Photography and the Landscape Tradition', Representations, 69, Special Issue: Grounds for Remembering (Winter), pp. 38-62.

Berkhoff, Karel, 2010. 'Pogolovnoe unichtozhenie evreiskogo naseleniia: Kholokost v sovetskikh SMI, 1941-1945', Holokost i Sučasnist', 1, (7), pp. 62-122.

Bessonov, Nikolai and Nadezha Demetr, 2000. Istoriia tsygan: novyi vzgliad, Voronezh.

Bielaruskaja Savieckaja Encyklapiedyja, volume 2, 1970, Minsk.

Blutinger, Jeffrey, 2010. 'An Inconvenient Past: Post-Communist Holocaust Memorialization', Shofar: An Interdisciplinary Journal of Jewish Studies, 29: 1, pp. 73-94.

Bratochkin, Aleksei, 2012. 'Preodolenie «sovetskogo proshlogo»v Belarusi kak problema', Belarusian Center for European Studies, 19 January <http://eurocenter.by/studies/preodolenie-sovetskogo-proshlogo-v-belarusi-kak-problema>. [accessed 28 January 2013].

Chiari, Bernhard, 1998. Alltag hinter der Front: Besatzung, Kollaboration und Widerstand in Weißrußland 1941-1944, Düsseldorf: Droste Verlag.

Czerniakiewicz, Jan, 2004. Przemieszczenia ludności polskiej z ZSRR 1944-1959, Warszawa: Wydawnictwo Wyższej Szkoły Pedagogicznej TWP.

Dean, Martin, 2000. Collaboration in the Holocaust: Crimes of the Local Police in Belorussia and Ukraine, 1941-44, New York: St. Martin's Press.

Dučyc, Larysa, 2003. 'Z historyi cyhanoŭ Bielarusi’, Bielaruski Histaryčny Časopis, 3, pp. 45-49.

Epstein, Barbara, 2004. 'Allies in Resistance: Jews and Belarusians in German-Occupied Minsk', in David Gaunt, Paul A. Levine and Laura Palosuo (eds.), Collaboration and Resistance during the Holocaust: Belarus, Estonia, Latvia, Lithuania, Bern, pp. 431-58.

Ficowski, Jerzy, 1989. Cyganie w Polsce. Dzieje i obyczaje, Warszawa: Interpress.

Fridman, Aliaksandr, 2004. 'Nieviadomy hienacyd: źniščeńnie bielaruskich cyhanoŭ u 1941-44 hh.', ARCHE, 2, pp. 2-13.

Ganzer, Christian and Alena Paskovic, 2010. 'Heldentum, Tragik, Tapferkeit. Das Museum der Verteidigung der Brester Festung', Osteuropa, 60. 12, pp. 81-96.

Gerlach, Christian, 1999. Kalkulierte Morde. Die Deutsche Wirtschafts- und Vernichtungspolitik in Weissrussland 1941 bis 1944, Hamburg: Hamburger Edition.

Gross, Jan Tomasz, 1988. Revolution from Abroad: the Soviet Conquest of Poland's Western Ukraine and Western Belorussia, Princeton, NJ: Princeton University Press.

Harecki, Haŭryla, 1929. 'Nacyjanaĺnyja asablivaści nasieĺnictva BSSR i bielaruskaha nasieĺnictva 
SSSR pavodlie pierapisu 1926 h.', Polymia, 3, pp. 84-85.

Hedlund, Stefan, 2005. Russian Path Dependence, London: Routledge.

Hiezhala, Siarhiej, 2012. 'Bielaruskija ŭlady nie dazvolili paviesić šyldu UPA ŭ bielaruskaj vioscy', Naša Niva, 5 November.

Holler, Martin, 2008. 'Die Nationalsozialistische Vernichtung der Roma in der Sowjetischen und Russischen Erinnerungskultur', Der Nationalsozialistische Genozid an den Roma Osteuropas, Köln: Böhlau Verlag, pp. 245-94.

Hryboŭski, Jury, 2006. 'Polska-bielaruski kanflikt u hienieraĺnaj akruzie «Bielaruś» (1941-1944 hh.)', Białoruskie Zeszyty Historyczne, 25, pp. 116-67.

_-_, 2007. 'Savieckija represyi ŭ zachodniaj Bielarusi (kastryčnik 1939 - červień 1941 hh.)', in I. Kuznetsov, Ia. Basin, Repressivnaia politika sovetskoi vlasti v Belarusi, volume 2, Minsk.

Kalinin, Valdemar, 2005. Zagadka baltiiskikh tsygan, Minsk: Logvinov.

Kapralski, Sławomir, 2012. 'Symbols and Rituals in the Mobilisation of the Romani National Ideal', Studies in Ethnicity and Nationalism, 12, 1, pp. 64-81.

Kotljarchuk, Andrej [review of] Gaunt, David, Paul A. Levine and Laura Palosuo (eds), 2004 Collaboration and Resistance during the Holocaust. Belarus, Estonia, Latvia, Lithuania, Bern: Verlag Peter Lang, in ARCHE, 3, 2005, Minsk.

- - - [review of] Bernhard, Chiari, 1998. Alltag hinter der Front: Besatzung, Kollaboration und Widerstand in Weißrußland 1941-1944, Düsseldorf: Droste Verlag in Ab Imperio, 3, 2007, pp. 482-92.

- - , 2012. V Kuznitse Stalina. Shvedskie kolonisty Ukrainy v totalitarnykh eksperimentakh XX veka, Moskva: Rosspen.

'Kuźniacoŭ: ŭ Kurapatach kožny maje prava stavić kryžy', Radyjo Svoboda, 5 December 2012 <http://www.svaboda.org/content/article/24790382.html>. [accessed 28 January 2013].

Lashkevich, Kastus', 2008. 'Pochemu belorusskie vlasti peresmotreli svoe otnoshenie k Kholokostu', Tut.by, 3 November <http://news.tut.by/society/120668.html>. [accessed 28 January 2013].

Lastovski, Aleksei, 2009. 'Spetsifika istoricheskoi pamiati v Belarusi: mezhdu sovetskim proshlym i natsional'noi perspektivoi', Vestnik Obshchestvennogo Mneniia, 4 (102), pp. 88-99.

Leizirov, A. T., 2006. 'Nekotorye aspekty otnosheniia sovetskogo rukovodstva k unichtozheniiu evreiskogo naseleniia na territorii Belorussii v gody okkupatsii', in Aktual'nye voprosy izucheniia Kholokosta na territorii Belarusi v gody nemetsko-fashistskoi okkupatsii: Sbornik nauchnykh rabot, volume 2, Minsk: Kovcheg.

Levin, L. M., 2010. 'K voprosu o memorializatsii mest massovogo unichtozheniia zhertv Kholokosta na territorii Belarusi', Uroki Kholokosta: Istoriia i sovremennost'. Sbornik nauchnykh rabot, volume 3, Minsk: Kovcheg.

Litskevich, Oleg, 2009. 'Liudskie poteri Belarusi v voine', Bielaruskaja Dumka, 5 May, pp. 9297.

Litvin, Aleksei, 2002. 'K voprosu o kolichestve liudskikh poter' Belarusi v gody Velikoi Otechestvennoi Voiny 1941-1945', in Bielaruś $\breve{u}$ XX Stahoddzi, volume 1, Minsk.

Lubachko, Ivan, 1972. Belorussia under Soviet Rule 1917-1957, Lexington: University Press of Kentucky. 
Lukashenka, Aleksandr, 2004, Vystuplenie na torzhestvennom sobranii, posviashchennom 60-I godovshchine osvobozhdeniia Respubliki Belarus ot nemetsko-fashistskikh zakhvatchikov i Dniu nezavisimosti Respubliki Belarus, 2 July <http://president.gov.by/press13450.html\#doc>. [accessed 28 January 2013].

- - - 2010. Stenograma vystupleniia na torzhestvennom sobranii, posviashchennom 65-oi godovshchine Velikoi Pobedy, 7 May <http://news.tut.by/press88741.html>. [accessed 28 January 2013].

Marples, David and Per Anders Rudling, 2009. 'War and Memory in Belarus: The Annexation of the Western Borderlands and the Myth of the Brest Fortress, 1939-1941', Białoruskie Zeszyty Historyczne, 32, pp. 225-44.

Masherov, Petr, 1965. 'Nepreoborimaia sila narodnaia', Sovetskaia Belorussiia, 8 May.

- - - 1969. 'Rech na torzhestvennom sobranii posviashchennom 25 godovshchine osvobozhdeniia BSSR ot nemetsko-fashistskikh zakhvatchikov', Sovetskaia Belorussiia, 5 July.

Mikulievič, Siarhiej, 2011. 'Dakumienty NKVD abviarhajuć Lukašenku', Naša Niva, 28 December $<\mathrm{http}: / / \mathrm{nn} . \mathrm{by} / \mathrm{c}=\mathrm{ar} \& \mathrm{i}=65784>$. [accessed 13 March 2013].

Morris, James, 2004. 'The Polish Terror: Spy Mania and Ethnic Cleansing in the Great Terror', Europe-Asia Studies, 50, 5, pp. 751-66.

Ničoha nie zabudziem, ničoha nie darujem: dakumienty ab źvierstvach niamieckich akupantaŭ na Bielarusi, 1943, Minsk.

Nora, Pierre and Lawrence D. Kritzman, (eds.), 1996-97. Realms of Memory: Rethinking the French Past, volume 1, Conflicts and Divisions (New York 1996), volume 2, Traditions (New York 1997).

Pase, U., 1994. 'Vialikaja Ajčynaja Vajna', in Encyklapiedyja historyi Bielarusi, volume 2, Minsk, pp. 433-34.

Paźniak, Zianon, 2012a. 'Kurapaty - 2012 hod', Bielaruskaja Salidarnaść, <http://www.bielarus.net/archives/2012/10/29/2848>. [accessed 28 January 2013].

- - - 2012b. 'Maskoŭskich pravakacyjaŭ u Kurapatach boĺš nie pavinna być', vystup na Śniežanskim Sojmie Bielaruskaha Narodnaha Frontu, http://www.bielarus.net/archives/2012/12/11/2912. [accessed 28 January 2013].

Paźniak, Zianon and Jaŭhien Šmahaloŭ, 1994. Kurapaty - The Road of Death, Minsk.

Perepis 2011. Table 1.2. 'Dinamika natsional'nogo sostava', Perepis Naseleniia 2009 h., volume 3, Minsk.

Petrov, Nikita and Arsenii Roginskii, 1997. «Pol'skaia Operatsiia» NKVD 1937-1938 gg.', Repressii protiv poliakov i polskich grazhdan, Moskva: Zvenia, pp. 22-43.

Pickford, Henry W., 2005. 'Conflict and Commemoration: Two Berlin Memorials', Modernism/Modernity, 12, 1, January, pp. 751-66.

Platonaŭ, Rascyslaŭ and Mikola Staškievič, 1993. 'Dźvie apieracyi suprać vorahaŭ naroda', Bielaruski Histaryčny Časopis, 1, pp. 73-80.

Portnov, Andriy, 2007. 'Uprazhneniia s istoriei po-ukrainski. Zametki ob istoricheskikh suzhetakh obshchestvenno-politicheskikh debatov v postsovetskoi Ukraine', Ab Imperio, 3, pp. 93-138.

Rein, Leonid, 2011. The Kings and the Pawns: Collaboration in Byelorussia during World War II, New York: Berghahn Books. 
Rozenblat, Evgenii and Irina Elenskaia, 2002. 'Dinamika chislennosti i rasseleniia belorusskikh evreev v XX veke', Diaspory, 4, pp. 27-52.

- - , 2003. 'Issledovaniia istorii Holokosta v Belarusi: Shag vperiod ili toptanie na meste?' in Krzysztof Buchowski and Wojciech Śleszyński (eds), Historycy polscy, litewscy i białoruscy wobec problemów XX wieku, Białystok: Instytut Historii Uniwersytetu w Białymstoku, pp. 49-60.

Rudling, Anders Per, 2010. 'Lukašenka i čyrvona-karyčnievyja: Dziaržaŭnaja idealohija, ušanavańnie minulaha i palityčnaja prynadležnaść', Palityčnaja Sfiera, 14, pp. 90-113.

- - , 2012. 'The Khatyn Massacre in Belorussia: A Historical Controversy Revisited', Holocaust Genocide Studies. (Spring), 26, 1, pp. 29-58.

Schabas, William A., 2000. Genocide in International Law. Cambridge: Cambridge University Press.

Schäuble, Michaela, 2011. 'How History Takes Place: Sacralized Landscapes in the Croatian-Bosnian Border Region', History and Memory, 23, 1, pp. 23-61.

Sherman, B. P., 1997. Baranovicheskoe getto. Koldychevskii lager'smerti, Baranovichy.

Shoŭkun, Voĺha, 2010. 'Pomnić, nieĺha zabyć', Astravieckaja Praŭda, 28 July.

Silitski, Vitali, 2005. 'A Partisan Reality Show', Transitions Online. 11 May <http://www.tol.org/cnt/article/14025-a-partisan-reality-show.html>. [accessed 28 January 2013].

Smilovitskii, L. L., 2010. 'Evakuatsiia i begstvo iz Turova. Leto 1942 g.', Uroki Kholokosta, Istoriia i Sovremennost': Sbornik nauchnykh rabot, volume 3, Minsk.

Soobshcheniia, 'Soobshchenie chrezvychainoi gosudarstvennoi komissii po ustanovleniiu zlodeianii nemetsko-fashistskikh zakhvatnikov i ikh soobshchnikov', Izvestiia, No. 205, 29 August 1944.

Stewart, Michael, 2004. 'Remembering without Commemoration: the Mnemonics and Politics of Holocaust Memories among European Roma', Journal of the Royal Anthropological Institute, 10, 3, pp. 561-82.

Tiahlyi, Mihajlo, 2011. 'Babin Jar jak misce masovoho viniščennia ukrainskich Romiv: Tipova model?', neopublikovannyi doklad na mezhdunarodnoi konferentsii «Babin Jar: Masove ubivstvo i pamiat' pro nioho», 24-25 October, Kyiv.

Törnquist-Plewa, Barbara (ed.) 2006. 'Remembering World War II in Belarus. A Struggle between Competitive Historical Narratives', in Barbara Törnquist-Plewa, History, Language and Society in the Borderlands of Europe. Ukraine and Belarus in Focus, Malmö: Sekel, pp. 33-60.

Turonak, Jury, 2008. 'Kožny čaćvierty i Kurapaty', Madernaja Historyja Bielarusi, Vilnius, pp. 678-83.

Uchwała Sejmu Rzeczypospolitej Polskiej z dnia 31 sierpnia 2012 r. w sprawie hołdu wszystkim zamordowanym i represjonowanym na terenach Związku Radzieckiego w ramach tzw. Operacji Polskiej w latach 1937-1938.

Ushakin, Sergei, 2001. 'V Poiskakh mesta mezhdu Stalinym i Gitlerom: o postkolonial'nykh istoriiakh sotsializma', Ab Imperio, 1, pp. 209-33.

Vakar, Nicholas, 1956. Belorussia: the Making of a Nation: A Case Study, Cambridge, MA: Harvard University Press.

Ventsel', T., 1978. 'Tsygane', Bol'shaia Sovetskaia Entsiklopediia, volume 28, Moskva, pp. 60607 . 